\title{
Нашият опит при скринингово изследване на слуха на новородени чрез ОАЕ
}

\author{
Кр. Бозов \\ УНГ-отделение, "МБАЛ-Шумен" АД
}

\section{Резюме}

През октомври 2006 г. в УНГ-отделение „МБАЛ - Шумен” стартира скринингово изследване на слуха при рискови новородени деца от Родилното отделение на „МБАЛ - Шумен” АД.

Използвана апаратура - автоматизирана диагностична система - клиничен MAICO ERO.SCAN с възможности за изследване на DPOAE и TEOAE.

За периода октомври 2007 г. - август 2008 г. се проведе изследване на 173 новородени деца с високи рискови фактори за слухови увреждания.

\section{Въведение}

Както е известно, дори слабите, но персистиращи слухови увреждания в детската възраст, ако не бъдат своевременно диагностицирани и съответно рехабилитирани, водят до забавено развитие на говора и речта. В световната практика са въведени различни протоколи за провеждане на слухов скрининг при новородени. Доколкото ни е известно, дори и в развитите Европейски страни няма изградена цялостна система, която да обхваща всички новородени.

\section{Протокол за скрининг}

Като напълно обективен, достатъчно кратък, неинвазивен и сравнително евтин метод за инициален слухов скрининг в повечето ръководства и публикации се приема изследването на ОАЕ.

От 2003 год. българските оториноларинголози и педиатри разполагат с „Методическо ръководство за ранно откриване на деца с увреждания на слуха“, разработено от доц. Й. Спиридонова и д-р П. Руев.

В нашата клинична практика сме възприели следния скринингов протокол:

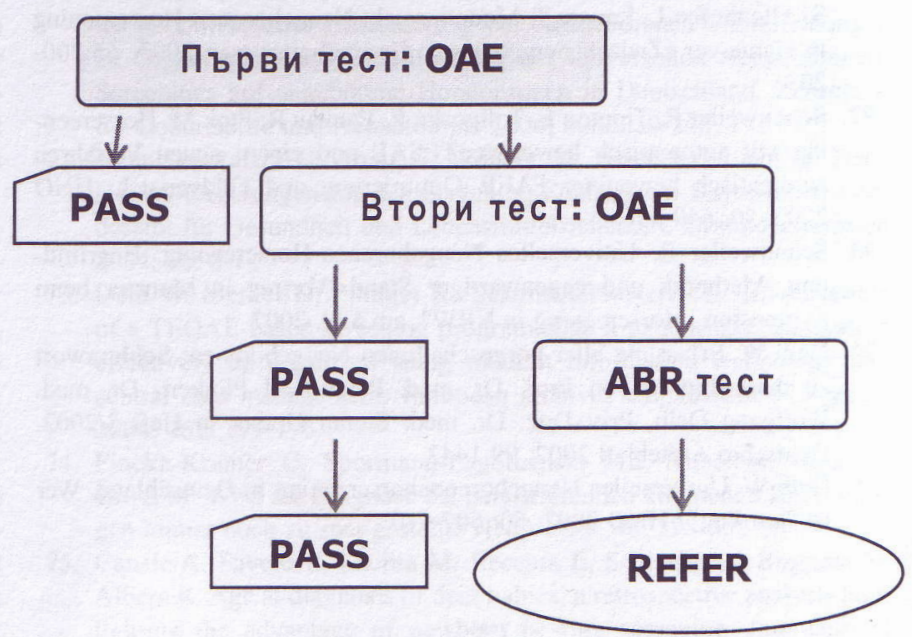




\section{МБ оториноларингология Ф્ळ}

\section{Материал и методи}

През месец септември 2006 г. УНГ-отделение при МБАЛ - Шумен бе оборудвано с автоматизирана диагностична система MAICO ERO.SCAN със следните технически характеристики:

1. Възможност за регистрация на DPOAE и TEOAE;

2. Честотен диапазон при DPOAE - 1,5 до $12 \mathrm{kHz}$, а при TEOAE - 0,7 до $4 \mathrm{kHz}$;

3. Интензитет на стимулация при DPOAE - 40 до $70 \mathrm{~dB}$ SPL, а при TEOAE - 83 dB SPL пиков еквивалент.

4. Максимална мощност до $90 \mathrm{~dB}$ SPL.

През октомври 2006 г. стартирахме скринингово изследване на рискови новородени деца от Родилното отделение на МБАЛ - Шумен. Изследването се прилага 2 пъти седмично, съобразно обичайния престой на децата в Неонатологично отделение. Провежда се от лекар, който оценява състоянието на външно и средно ухо.

В проведения от нас слухов скрининг сме използвали основно TEOAE. В сравнение с DPOAE те ни дават следните предимства:

1. Не налагат висока степен на шумоизолация на помещенията;

2. Съкратено е времето за изпълнение на изследване.

Подборьт на децата е съобразен с предварително подготвен въпросник относно рисковите фактори за слухови увреждания.

\section{Резултати}

За периода октомври 2007 г. - август 2008 г. се проведе изследване на 173 новородени деца със следните резултати:

При 10 деца $(5,78 \%)$ не се регистрираха OAE от пьрвия тест (т.е. 5,4 на хиляда от общия брой новородени - 1849). При 5 от децата се установи отрицателен отговор за двете уши - 2,7 на хиляда. При 5 от децата - за едното ухо.

\section{Обсъждане}

Налице е корелация с данните от световните статистики, в които крайният процент варира от 1 до 2 на хиляда.

На децата с данни за увреждане на слуха при първото тестуване беше проведено повторно тестуване с TEOAE, респ. DPOAE. Не преминалите и втори тест бяха подложени на изследване с конвенционална BERA.

\section{Заключение}

Независимо от краткото време на проведения скрининг и ограничения брой на изследваните деца нашите резултати ни дават основание да смятаме, че използваният скринингов протокол има своето място в ранната диагностика на глухотата, като предпоставка за своевременна рехабилитация на слуха и говора.

\section{Литература:}

1. Руев П, Спиридонова Й. Многоетапен протокол за провеждане на универсален нсонаталсн слухов скрининг (УНСС). 2003

2. Милков М., Е. Ценев, И. Ценев, Д. Марев. Отоакустични смисииссенциален поглед. Международен бюлетин по оториноларингология, 25-30, брой 3, 2007 г.

3. Kemp, D.T. 1978 , stimulated acoustic emissions from within the human auditory system. Journal of the Acoustical Society of America.

4. Probst, R., Coast, A.C., Martin, G.K. and Lonsbury-Martin, B.L., 1986, Spontaneous, click, and tone-burst-evoked oto acoustic emissions from normal ears. 